\title{
PROBLEMS IN TEACHING TOURISM REGISTER FOR ENGLISH SPECIFIC PURPOSES (ESP) CLASS
}

\author{
Dewa Ayu Kadek Claria \\ Universitas Warmadewa \\ clariadewaayu@gmail.com
}

\author{
A.A. Istri Manik Warmadewi \\ Universitas Warmadewa
}

\begin{abstract}
The purpose of this research was to find out the problems in teaching tourism register in English Specific Purposes (ESP) class. Students are expected to know the tourism register as the new group of vocabulary and being able to use them in the related field. When the tourism register is implanted in the course, there were some problems appeared. By reading many literatures related to the topic, the problems can be investigated. It was found that there are some problems which influenced the teaching method in ESP class. The problems can be generalized into two main problems namely; the lecturer's problems and student's problems. The lecturer's problems consist of ineffective teaching and learning method includes the design material which is not fit enough for some ESP students. The student's problems are divided into the student English proficiency, lack of vocabulary, lack of motivation and basic skill in reading, writing, listening and speaking skills.
\end{abstract}

Keywords: Tourism Register, ESP, English for Specific Purposes

\section{INTRODUCTION}

The English Specific Purposes (ESP) class exist due to the growth of tourism industry and the awareness of the English quality which need a suitable course for the English Department students as the learner. There are many subdivisions for ESP class and one of them is the English for Tourism. The methodology used in teaching English for tourism especially the register in ESP class as the topic should be designed properly so it can fulfil the learner's need. In teaching language, the learning success is depends to the lecturer role and the learner characteristics. (Suzani, 2011). In teaching tourism register in ESP class by using SFL theory, the typical of grammatical and lexical occur in the target register. Halliday (1973) suggest that in the scope of language education, the term of language has a lot of interpretation. The interpretation can be based on the culture and context. By those explanation, it can be said that the teaching concept for ESP class especially the tourism register as the topic can build the potential language education as the students will have a new vocabulary includes the context and culture for a particular field. Hutchinson \& Waters (1987) found that there are three reasons of the emergence in learning a new thing through ESP. Those three things are the revolution in linguistics, demands of the input of a new world and the new learning focus as in some country teaching the English Specific Purpose has turned into a new trend. They defined that ESP as the way for language learning which is based on learner need. Based on those explanation, it can be said that the course which 
means the material and syllabus in ESP class are adjusted and depend with learners' desire.

Register is the approach of communicative situations in particular social setting which caused the register has some varieties for a particular purpose. One of them is in tourism industry. According to Pickett (1986), the attention to situational context of the text bring the impact to the right choice of the word in the right place without leaving the intended message. The interaction in tourism industry is not only found in the spoken text but also the written text, so the use of register adapted in both fields. Registers in tourism are used as a tool for someone in a group to make them easier in understanding the meaning or the message of text by creating a new word or term for the group. The forms of register in linguistics unit represent as a word, acronym or phrase. Since the register in one community cannot be understand by someone who are not involved within that community, it becomes very important to introduce the register, especially about the tourism industry for the students who take the ESP class majoring the hospitality as a learner. Many interesting researches about register have been done up to now. Purnomo (2016) analysed about the function of register in tourism service providers and their sociocultural meaning. He found that the register used by the tourist are utterances and it has specific meaning. Another research about register analysis in teaching and learning proposed by Rose and Martin (2012) said that in interpreting a register, the pattern of language can be used a tools guide. In teaching register, lecturers use presenting knowledge, directing activities, soliciting responses and evaluating learners. Meanwhile Figuedero (2016) said that the level of register in linguistics choices as the element that mediates a genre can be found in specific text structure. Shahamatun (2014) revealed that register as variety of language use by midwives in maternity clinic influenced by the foreign words, phrases, acronyms and abbreviation which only known by a midwife as their profession. Sudaryanto (2014) described the characteristic of register use by the busker in Surakarta into five types, they are Javanese dominated, code mixing and switching between Indonesian Language and Javanese, shift change for the words meaning, create a new simple form of language, impolite and slang words, and quite intimate word as a variety. As mention previously that register used by the group of people with the same purpose, Inderasari (2018) share the result of her research showed that there was 50 new registers in the form of word for the bus crew at Tirtonadi Surakarta Station. Those new words created as register pattern which is a special word with new meaning used by the community between the bus crews.

Teaching tourism register in ESP class in this era is quite challenging. The course has to meet the learner' need so it is very important to find out the problems appear where the materials or topics are delivered. In this case, the learner need is not only about the English in general but also the introduction to new vocabulary about tourism register. By taking ESP course, the students are hoped to have a new vocabulary which is specialized in tourism so that they are able to use them in the future. The problems in teaching tourism register has to reveal to make the teaching process successfully.

\section{LITERATURE REVIEW}

Purnomo (2011) classified the tourism register into fourteen activities namely; meeting tourist, receiving reservation, information upon arrival, telephone 
inquiries, checking in, giving direction, entertainment information, describing itinerary, describing tour route, restaurant conversation, making art project, bargaining prices for souvenir, describing tour sites and check out. In teaching register for English Department students in English Specific Purpose (ESP) class, the concept of register must be introduced from the small unit called word which exists in various activities. Based on the previous research and theories, the form of register seen from the lexico-grammatica and the activity are the basic learning item in teaching register for ESP class. The concepts of register in tourism industry belongs to applied linguistics and it divided into two types of variation; they are based on the user and the use of language itself. It simply said that register is being produced by the social situation. In tourism industry, they have typical expressions to communicate in the community namely tourism register. Based on the types, register can be divided into three types, they are register in the form of word, register in the form of phrase and register in the form of abbreviation. Those types can be seen as below;

\section{Tourism Register in the Form of Word}

Register in the form of word in this research consist of adjective, noun, and verb. Word is unit of language which is consist of sequences of letters and it becomes a part of learning language. There are word class in every languages to show the function of each word. In English, they are adjective, noun and verb. Adjective is basically has a function to modify a noun. Noun is a word used to identify every things, places or people and verb is a word which is used to describe an action and forming the main part of sentence.

Register in tourism industry which take place as the adjective, noun and verb can be seen in the dialogue below;

Table 1. The dialogue between receptionist and guest

\begin{tabular}{|c|l|l|}
\hline No & Name & \multicolumn{1}{|c|}{ Dialogues } \\
\hline 1 & Guest & $\begin{array}{l}\text { Why do you have to show us or perform a lot of cultural } \\
\text { things including the popular dance such as Kecak in this } \\
\text { festival? }\end{array}$ \\
\cline { 2 - 3 } & Reception & $\begin{array}{l}\text { This festival aims to preserve our heritage of Balinese Culture. } \\
\text { We also have the shows of the ancient dance which you can } \\
\text { enjoy at certain events or ceremony in Bali. }\end{array}$ \\
\hline 2 & Guest & $\begin{array}{l}\text { My partner has made a request to visit Sanur Village Festival to } \\
\text { have some brunch right there tomorrow. What do you think? }\end{array}$ \\
\cline { 2 - 3 } & Reception & $\begin{array}{l}\text { I think you have to approve it, Sir. The Sanur Village Festival is } \\
\text { the festival that you cannot be missed. }\end{array}$ \\
\hline \multirow{2}{*}{3} & Ruest & $\begin{array}{l}\text { I will check in at 22.00 PM tomorrow. Is it possible to visit } \\
\text { Sanur Village Festival at late night? }\end{array}$ \\
\cline { 2 - 3 } & Reception & $\begin{array}{l}\text { I recommend you to go earlier Sir, because you will run out of } \\
\text { the good food and performance since it closes at 23.00 PM. }\end{array}$ \\
\hline
\end{tabular}


The words popular, heritage and ancient in the example on dialogue 1 are the example of adjective words that is commonly use in tourism industry. Those adjective word usually related to places or events which has a function to modify the places or events as the noun. In the dialogue 2 , the words request and brunch are represent the noun in tourism industry meanwhile the dialogue 3 shows us the use of verb in tourism industry through the words recommend and visit. All those words in every word class are in use in the same context situation of tourism industry, so it can be said that all those words are the register of tourism industry in the form of word.

\section{Tourism Register in the Form of Phrase}

The tourism industry also has their own phrase as the register. The phrase which is used by people in tourism industry is an unfamiliar one to the person who does not know or not involve in the group. Those specific phrase also categorized as the register in tourism industry. For the example, the phrases that commonly use such as below:

Table 2. The dialogue between receptionist and guest

\begin{tabular}{|c|c|l|}
\hline No & Name & \multicolumn{1}{|c|}{ Dialogues } \\
\hline \multirow{2}{*}{1} & Reception & Mind your steps, Sir! \\
\cline { 2 - 3 } & Guest & Thank you. \\
\hline 2 & Reception & Mind your head, Mam! \\
\cline { 2 - 3 } & Guest & Well, all right. Thank you. \\
\hline
\end{tabular}

Those phrases are often used in hospitality industry by the hotelier. The dialogue show us that the phrases "Mind your steps" and "Mind your head" are the phrase which has the function to remind someone to be careful in walking or stepping. In hospitality industry, it is really common to show that the hotelier need to put a big attention to the guest safeties. When we have to teach the register in the form of phrases which is usually use in tourism industry, the meaning of the register and the function also need to be discussed because some students are unfamiliar with the tourism register.

\section{Tourism Register in the Form of Abbreviation}

An abbreviation is a process of shortened form of word or phrase. Abbreviation take many forms with purpose to make sentences easier to read. Abbreviation take different shape of varieties such as by combining the first letter or initialize the letter. Abbreviation can be used for courtesy titles or academy degrees, times, dates, places, and units of Measurement. In tourism industry, there are lot of abbreviations used as the tourism register which has function as the code between the hotelier or even traveler example of register that can be found in tourism industry can be seen as below:

Table 3. Abbreviations of tourism register

\begin{tabular}{|c|c|c|}
\hline No & Abbreviation & Definition \\
\hline 1 & FIT & Foreign Independent Traveler \\
\hline 2 & GIT & Group Independent Traveler \\
\hline
\end{tabular}




\begin{tabular}{|c|c|c|}
\hline 3 & WIG & Walk in Guest \\
\hline 4 & TA & Travel Agent \\
\hline 5 & RO & Room Only \\
\hline 6 & RBF & Room and Breakfast \\
\hline 7 & PA & Personal Account \\
\hline
\end{tabular}

The tourism register FIT, RO, RBF, WIG, TA, PA, and MICE is the register in the form of abbreviation which is commonly used by the community in tourism field. This abbreviation has been used from time to time with the intention to make the conversation or the report are not taking too much space and simply understand in the required time. FIT is the abbreviation of "Foreign Independent Traveler" as well as GIT is the abbreviation of "Group Independent Traveler". Both of them are kind of traveler who are usually booked the hotel by the email or phone number which are provided by the hotel. FIT also known as solo traveler and GIT is someone who travel with the group of minimum three people. They are categorized as FIT or GIT in the hotel system to make the worker easier either in pronounce or remember them. Meanwhile the abbreviation of WIG which has meaning as "Walk in Guest" and TA which has meaning as "Travel agent" is also the way of the guest to book the hotel. WIG is the guest book the hotel and check-in in the same time and TA is the guest book the hotel through the travel agent with the certain time. The other kinds of abbreviation which is commonly used are RO, RBF, and PA. $\mathrm{RO}$ is the abbreviation of "Room Only", RBF is the abbreviation of "Room and Breakfast" and PA is "Personal Account". Those three register is usually used for the guest billing. The guest booked the room only will get the mark RO in the system and RBF is the guest who booked the room and breakfast. The billing of RO and RBF is charged to the guest personal account which is known as PA or it may be charged to TA or company which depends to the guest booking.

\section{The Concepts of English Specific Purposes}

Many definitions describe ESP as teaching English for any purposes. The ESP usually applied for adults who already has basic English Language proficiency. Teaching English with purposes are applied in academic studies for non-native speakers. There are many subdivision of ESP such as English for Accounting, English for Computer, English for Business, English for Medical and also English for tourism. The learning success in teaching ESP depends on several things, they are the learners' ability to follow the course and the lecturers' role to guide the learner. Besides, it also depends on the teaching materials such as syllabus, book reference or textbook. Those factors become the basic foundation in teaching ESP. In teaching ESP, it cannot be separated from the problems arise since every process has a big potency of discrepancy lays behind it. According to Hutchinson \& Waters (1987), ESP will always define to meet the specific needs of the learners and it may be created or designed based on specific disciplines or situations. Learners need are the problems in teaching ESP. Suzani (2011) found that the learners had some issues in ESP class. They are the inappropriate time for conducting ESP, the class condition which lead the students could not concentrate, the postpone material, the learners' motivation reduce every week, the incompatibility between the ESP course with their previous knowledge and the teaching method.

The course in ESP has to be designed and prepared by the lecturer based on learning need and students need to make the teaching process meet the expectation 
with the good result. The course basically using the English Specific Purposes (ESP) theory with three main elements. The first one is creating authentic material which consists of communicative task. The second one is apply the students centered learning to make the students become more active. The last one is always improved the course by doing the evaluation. The lecturer who plays role as course designer, material provider, researcher, collaborator and evaluator need to have a good performance in teaching. Meanwhile the students as the learner in ESP are in charge in developing their English language skills and in this case in the tourism industry by using the register which has been used for years as their opportunity to get a new vocabulary.

\section{METHOD}

The participants in this research were 20 students in 1 class from English Department of Warmadewa University who take the ESP class in the sixth semester. From 4 classes, only 1 class taken and they were selected by filled in the questionnaire. The purpose of using the questionnaires are to find out the class which their participants had the most problems in understanding tourism register in ESP class. The students came from various living background in their family such as farmer, civil worker, banker and even hotelier. They had to take the ESP class as the mandatory to fulfil the grade requirement. The ESP class has been created base on the public demands since the University is located in tourism object and the students was from English Department where they really need to know the tourism register which has been wrapped ad designed into the ESP class. The period of the ESP class was in one semester with fourteen times class meeting and two times formal class evaluation. The meeting consists of 2 times face to face meeting, and the rest or 12 times online meeting due to the corona virus.

The evaluation given in every meeting at the end of the class, but there are two times formal evaluation called middle test and final test which has function to find out the progress of the students in the half semester and also in the end of the semester.

The topic of tourism register are one of the topic which has been delivered in ESP class. Even though it was delivered only for 2 times in the semester but the register actually used in the entire semester as the basic concept for ESP class which is focusing on tourism. Since the meeting has a limitation, the course need to be designed in effective ways. The concept register has been delivered from the basic form of the register into the use of register in tourism. The form of register can be seen from the word, phrase and abbreviation, meanwhile the uses of register can be seen from the daily dialogues in tourism industry. While teaching the tourism register in ESP class, the problems arise also revealed in the research.

\section{FINDINGS AND DISCUSSION}

This research tries to figure out the problems in teaching register especially in tourism industry. Teaching the tourism register for ESP class becomes so challenging due to the instructor or lecturer need to give an extra attention in designing the course or applied the correct method to deliver the material for the good result in ESP class.

From the explanation about register in tourism industry above, we know that all perspective about tourism register can be valuable for second language learner 
as they give a new information about the new term and meaning. It can enrich student's knowledge in this case for tourism field. The notions of register is actually used to make students aware with the language.

In learning register in tourism industry is a particularly complex one, since it needs context of situation rapprochement beyond the classroom environment. Learning foreign language as second language acquisition involves a big consideration in the amount of time and dedication. The learner expect the development in their ability as the payoff of their efforts. The English Department students need to learn the concept of register in tourism industry as the learning need. To determine whether the students need to learn the tourism register in a such way and the problems face by the student while took the course, the need analysis by using Hutchinson \& Waters (1987) theory has been used previously. In evaluating the ESP class, the target needs contribute the learner need include the lacks, wants and necessities. By learning register in English especially in tourism industry enables the students to use English that they have known before.

The tourism register itself already has complexity and it needs to be delivered to the students without arise to much problems. But in facts, the problems always came up in any course. By doing this research, it is hoped that we can anticipate the same problems in the future. The student's need are the biggest problem in teaching ESP. The students' expectation always lead the course have complains in some aspects. Based on the explanation above, problems in teaching English for ESP can be categorized into two main problems. They are student's problems and lecturer's problems.

\section{Lecturer's Problems in Teaching Tourism Register}

The first problem is concerned with lecturers. The teaching method that required the learner to memorize only the term of tourism register was not the best choice in teaching tourism register in ESP class. Even the tourism register is almost a hundred percent about memorization but the method needs to combine with the practice, quiz and games. After solving the problems, the students as centered learning has time to figure out the other tourism register concept and then discuss those new tourism registers in the group. As the evaluation, the students need to fill in some questionnaire which consist of the assessment of how the lecturer delivered the material of tourism register that they have learned before.

From the evaluation, it was found that 14 students out of 20 has been mastering the tourism register with no problems which means they do not have any problem in understanding the tourism register by using the lecturer's designed material, 4 students declare that they have some issues with the teaching method where they think that the materials is much for them so sometimes they have to take some extra time to cover all the task given by the lecturer and the rest of the students cannot meet the expectation at all because they want that the material designed in simple way such as by giving the effective explanation and complete them with the example of how they use it in real life.

Teaching register in the form of word is actually need some extra effort because the lecturer needs to prepare several techniques so the students can absorb the knowledge easily. The lecturer needs to avoid the memorizing method which usually lead to unsuccessful course. The lecturer needs to introduce something new and focus to the students' need at the same time. The tourism registers in the form 
of word need to be delivered in the form of dialogues so the students' can easily understand the use of those words or predict the meaning. The tourism registers in the form of word which has been designed in the form of dialogue can be seen as below;

Table 4. The dialogue between receptionist and guest

\begin{tabular}{|c|c|l|}
\hline No & Name & \multicolumn{1}{c|}{ Dialogues } \\
\hline 1 & Guest & $\begin{array}{l}\text { I would like to have brunch at the hotel restaurant tomorrow. They } \\
\text { offer special price for the buffet. Do you want to join? }\end{array}$ \\
\cline { 2 - 3 } & Reception & That is a great idea. \\
\hline
\end{tabular}

The tourism register in the form of word "brunch" and "buffet" above has been designed in the form of dialogue so the student can figure out the meaning of those word by reading all the dialogue. For some students this is the best way to learn a new vocabulary even though for the others this might be still not enough. That is the problem of lecturer in teaching tourism register in ESP class. The lecturer always requires to have the new ideas to meet the students' expectation or students' learning need.

\section{Student's Problems in Learning Tourism Register}

There are lot of register in tourism industry which need to be discovered by the students. As the learner, the students find some difficulties to understand of each new register including the meaning and when they have to use register itself in tourism industry. The difficulties usually related to the lack of motivation from the students, the inconvenience class, or the teaching and learning method which is still far from attractive.

Apart from those three difficulties, there are some cases which becomes the general problems in learning tourism register in ESP class. They are; the students' English proficiency, lack of vocabulary, and basic skill in reading, writing, listening and speaking skills. Student's ability or their basic skill in English are the most important things for them to follow the ESP class. When they do not have the skills, it becomes the huge problems. For the students, the ability to understand about the register in tourism industry can be both easy and difficult at the same time to be understood. So it can be said that the problems is actually about deals with students' ability.

The students' ability is the mark for the successful course. This is also reduce the students' motivation, because if since in the beginning they do not know what they learn, the unsuccessful course will be the result of teaching tourism register in ESP class by the end. For the example the dialogue between a foreign guest and the receptionist below show us that the term and abbreviation only can be understood by the person who already involved in tourism industry, so to deliver those terms to the students in ESP class smoothly, at least they have the basic English proficiency or the motivation to improve their knowledge. 
Table 5. The dialogue between receptionist and guest

\begin{tabular}{|c|c|l|}
\hline No & Name & \multicolumn{1}{|c|}{ Dialogues } \\
\hline 1 & Reception & $\begin{array}{l}\text { Hello Mr. Shawn, we would like to inform you that you still } \\
\text { have some outstanding bill to settle. Please advise us your } \\
\text { payment method? }\end{array}$ \\
\cline { 2 - 3 } & Guest & Please charge to my PA (Personal Account) \\
\hline
\end{tabular}

Some students in ESP class find the difficulties to learn the tourism register in the form of abbreviation because of their basic knowledge of their English proficiency was not improved yet and also the lack of their vocabulary. To understand the dialogue above, the materials should be arranged from the basic term of tourism register which is formulated in the form of the word, phrase and then continue to the register in the form of abbreviation as mention above with the authentic material and in the effective ways. The effectiveness shown from the material which concern only on the term of register in tourism industry. The materials was design as effective as it could, so there are no too many materials in one meeting to be mastered. It makes student easily to understand the new concept of register. Those dialogue is easily to understand by the guest, receptionist or someone who involved in this field but it need further explanation when we teach that term to the students. It was very unfortunate that somehow the teaching method from the lecturer also become the problems in teaching ESP.

\section{CONCLUSION}

Teaching tourism register in English Specific Purpose (ESP) class is necessary in English Department. Teaching ESP based on target need and learning need with the authentic and effective materials of tourism register lead the students to absorb all the knowledge which has been designed and lead the course successful as the purpose of the course. There are some problems found in teaching ESP which are categorized into two major problems; student's problems and lecturer's problems. Those problems has been solved by the revised material which is designed to fulfil the learner's need. By the end the course shows a good result where $70 \%$ of the students in ESP class already mastering the tourism register while the rest still need attention. Some suggestions are arise in teaching ESP class in the future especially in the term of tourism register. The first one is before teaching the ESP class, the learner basic knowledge need to be considered by creating a questionnaire of learner need. The questionnaire is the foundation of course design. Second one is improving the teaching method to make sure all students understand the course. The last one is the limitation in teaching the topic of tourism register need a suitable course where the students can absorb the knowledge easily.

\section{REFERENCES}

Figuedero, G. (2016). On Register Dynamics: From Systemic Variation to the text typology. Bandung: International Systemic Functional Congress. 
Figueiredo, D. (2010). Context, Register and Genre: Implications for language education. Brasil: Revista Signos

Halliday, M.A.K. (1973). Exploration in the Functions of Language. London: Edward Arnold.

Halliday, M.A.K \& Hasan, R. (1989). Language, context and text: Aspects of language in a social semiotic perspective. London: Oxford University Press.

Hutchinson, T., \& Waters, A. (1987). English for Spesific Purposes: A Learning Centered Approach. Cambridge: Cambridge University Press.

Inderasari, E. \& Oktavia, W. (2018). Pemakaian Bahasa Kru Bus Akap di Terminal Tirtonadi Surakarta. DIALEKTIKA: Jurnal Bahasa, Sastra dan Pendidikan Bahasa dan Sastra Indonesia.

Purnomo, Budi. (2011). Politeness in Tourism Service Register in Central Java: A Sociopragmatic Study. Yogyakarta: Gadjah Mada University.

Purnomo, Budi. (2016). Tourism Register: A Sociocultural Linguistic Study. International Seminar Prasasti III : Current Research Linguistics, 177-183

Rose, D and J.R. Martin. (2012). Learning to write, reading to learn: Genre, knowledge and pedagogy in the Sydney School. London: Equinox.

Shahamatun, A.D. (2014). Penggunaan Register Profesi Bidan di Klinik dan Rumah Bersalin di Delta Mutiara Sukodono, Sidoarjo. Skriptorium, Vol. 2, No. 2.

Sudaryanto, M., Sumarwati \& Edy, S. (2014). Register Anak Jalanan Kota Surakarta. BASASTRA : Jurnal Penelitian Bahasa, Sastra Indonesia dan Pengajarannya. Vol. 1, No. 3.

Suzani, S.M., Yarmohammadi, L., \& Yamini, M. (2011). A critical review of the current situation of teaching ESP in the Iranian Higher education istitutions. The Iranian EFL Journal, 7(6), 179-204. 